\title{
Perancangan dan Analisa Sistem Kemudi dan Sistem Suspensi Quadrilateral Pada Narrow
}

\author{
Tilting Vehicle
}

\author{
Rizal Pribadi Restuaji, dan Unggul Wasiwitono \\ Jurusan Teknik Mesin, Fakultas Teknologi Industri, Institut Teknologi Sepuluh Nopember (ITS) \\ Jl. Arief Rahman Hakim, Surabaya 60111 Indonesia \\ e-mail: unggul@me.its.ac.id
}

\begin{abstract}
Abstrak-Narrow tilting vehicle sebagai jenis transportasi alternatif yang menggabungkan sepeda motor dan mobil terus berkembang. Kendaraan beroda tiga ini mampu bermanuver dengan lincah karena memiliki kemampuan untuk memiringkan rangka kendaraan (tilting) seperti sepeda motor. Kemampuan bermanuver ini perlu didukung oleh sistem kemudi dan sistem suspensi kendaraan yang baik sehingga kendaraan tetap aman pada saat digunakan. Berdasarkan permasalahan tersebut diperlukan rancangan sistem kemudi dan sistem suspensi narrow tilting vehicle yang sesuai dengan kriteria tertentu. Proses perancangan sistem kemudi dan sistem suspensi narrow tilting vehicle dilakukan dengan simulasi kinematika menggunakan perangkat lunak multibody dynamics. Dari hasil simulasi diperoleh geometri sistem kemudi yang paling mendekati kondisi Ackerman adalah pada trackwidth $600 \mathrm{~mm}$ dan panjang sambungan belakang (Lack) $50 \mathrm{~mm}$ dan sambungan samping $\left(L_{\text {side }}\right) 40 \mathrm{~mm}$. Untuk geometri sistem kemudi yang paling mendekati kondisi Ackerman, variasi panjang upper control arm yang sama dengan lower control arm telah dipilih.
\end{abstract}

Kata Kunci-Narrow tilting vehicle, simulasi kinematika, sistem kemudi, sistem suspensi, sudut camber.

\section{PENDAHULUAN}

$\mathrm{N}$ ARROW tilting vehicle sebagai jenis transportasi alternatif yang menggabungkan sepeda motor dan mobil terus berkembang. Kendaraan beroda tiga ini mampu bermanuver dengan lincah karena memiliki kemampuan untuk memiringkan bodi kendaraan (tilting) seperti sepeda motor. Narrow tilting vehicle juga mempunyai rangka pelindung menyerupai mobil sehingga lebih aman dari sepeda motor. Kemampuan bermanuver ini perlu didukung oleh sistem kemudi dan sistem suspensi kendaraan yang baik sehingga kendaraan tetap aman pada saat digunakan.

Berdasarkan permasalahan tersebut diperlukan rancangan sistem kemudi dan sistem suspensi narrow tilting vehicle yang sesuai dengan kriteria tertentu. Sistem kemudi yang baik adalah yang mampu menghasilkan sudut belok sesuai dengan kondisi Ackerman [1]. Sedangkan sistem suspensi kendaraan harus dirancang agar menghasilkan sudut camber negatif ketika terjadi wheel displacement ke atas dan sebaliknya [2]. Dalam penelitian ini dilakukan simulasi kinematika untuk memperoleh rancangan sistem kemudi dan sistem suspensi narrow tilting vehicle sekaligus mengetahui pengaruh perubahan panjang sambungan batang kemudi dan trackwidth terhadap sudut belok yang dihasilkan serta mengetahui pengaruh perubahan panjang upper control arm terhadap perubahan sudut camber narrow tilting vehicle.

\section{METODOLOGI}

\section{A. Prosedur Perancangan}

Prosedur perancangan sistem kemudi dan sistem suspensi pada penelitian ini dibagi menjadi empat tahap. Tahap pertama adalah melakukan studi literatur mengenai perkembangan narrow tilting vehicle yang sudah ada beserta sistem kemudi dan sistem suspensi kendaraan tersebut. Tahap kedua adalah menentukan konfigurasi dan spesifikasi awal dari narrow tilting vehicle yang akan dirancang. Tahap ketiga adalah melakukan survei ketersediaan komponen penunjang sistem kemudi dan sistem suspensi di pasaran agar rancangan yang diperoleh dapat dibuat. Tahap terakhir adalah pembuatan model 3D sesuai rancangan awal dan melakukan simulasi kinematika menggunakan perangkat lunak multibody dynamics.

\section{B. Perancangan dan Analisa Sudut Belok Sistem Kemudi}

Setelah model 3D dibuat pada perangkat lunak multibody dynamics seperti terlihat pada gambar 1, dilakukan simulasi kinematika dengan memberi input pada sambungan batang kemudi untuk mengetahui perubahan sudut belok roda dalam $(\delta i)$ dan sudut belok roda luar $(\delta o)$. Perubahan sudut belok yang diperoleh dari hasil simulasi ini kemudian dibandingkan dengan kondisi Ackerman yang dijadikan sebagai acuan.

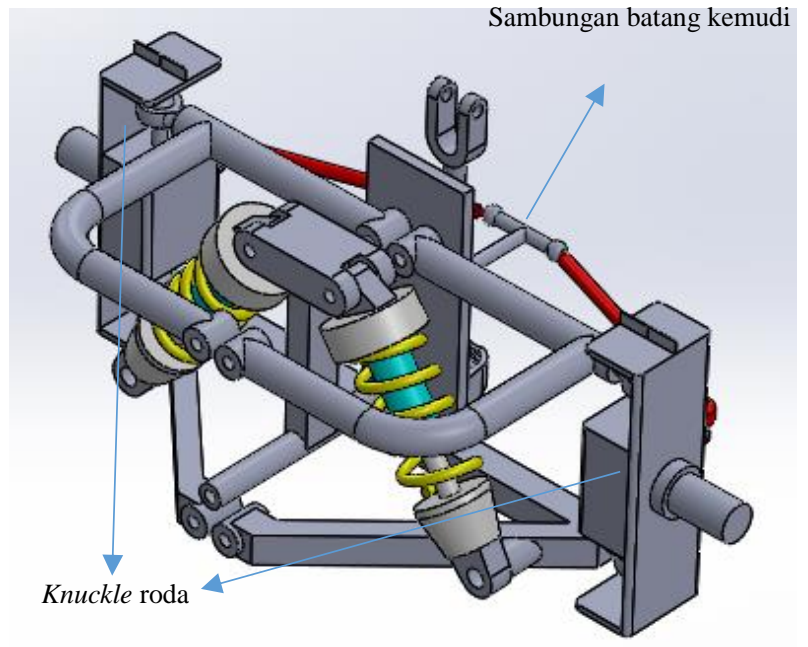

Gambar. 1. Rancangan awal sistem kemudi.

Untuk memperoleh hasil rancangan yang paling mendekati kondisi Ackerman sekaligus mengetahui pengaruh perubahan trackwidth dan panjang sambungan batang kemudi terhadap sudut belok yang dihasilkan, maka dilakukan simulasi pada tiga 
trackwidth yang berbeda yaitu $700 \mathrm{~mm}, 600 \mathrm{~mm}$, dan $500 \mathrm{~mm}$. Pada setiap trackwidth terdapat 3 variasi panjang sambungan belakang ( $\mathrm{L}_{\text {back }}$ ) dan 5 variasi panjang sambungan samping ( $\left.\mathrm{L}_{\text {side }}\right)$ seperti terlihat pada gambar 2.

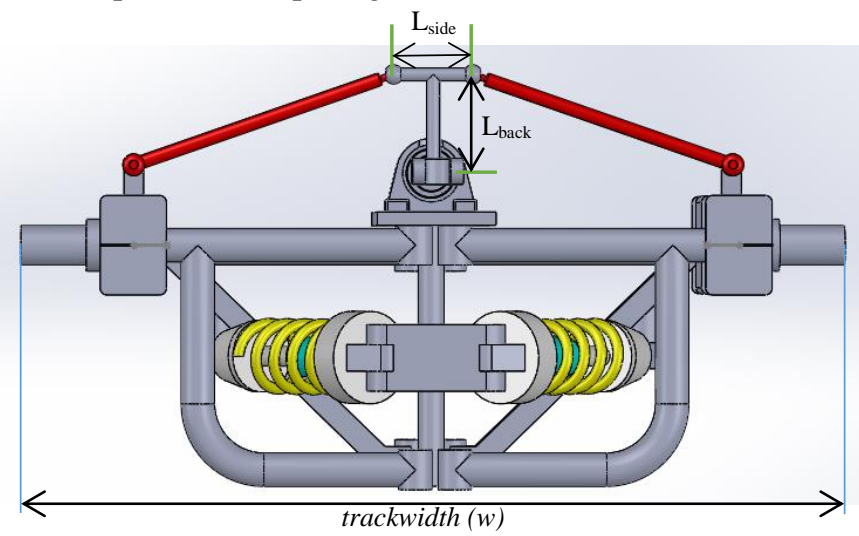

Gambar 2. Sambungan belakang dan samping batang kemudi.

Setelah simulasi dilakukan, data perubahan sudut belok kemudian di-plot dengan grafik Ackerman yang dirumuskan[1]:

$$
\cot (\delta o)-\cot (\delta i)=\frac{w}{l}
$$

Dimana $\delta o$ adalah sudut belok roda luar, $\delta i$ adalah sudut belok roda dalam, w adalah panjang trackwidth kendaraan, dan 1 adalah jarak sumbu roda depan dan belakang kendaraan.

\section{Perancangan dan Analisa Sudut Camber Sistem Suspensi}

Setelah simulasi kinematika pada sistem kemudi dilakukan, dipilih geometri sistem kemudi yang paling mendekati kondisi Ackerman. Pada geometri yang dipilih selanjutnya akan dilakukan simulasi kinematika untuk mengetahui perubahan sudut camber terhadap wheel displacement. Variabel yang divariasikan pada simulasi kali ini adalah selisih antara panjang upper control arm dengan lower control arm yang dinotasikan dengan $\delta$ dimana $\delta=\mathrm{L}_{\text {upper }}-\mathrm{L}_{\text {lower }}$. Terdapat 5 variasi nilai $\delta$ yaitu $\delta_{1}=-20 \mathrm{~mm}, \delta_{2}=-10 \mathrm{~mm}, \delta_{3}=0 \mathrm{~mm}, \delta_{4}=+10 \mathrm{~mm}$, dan $\delta_{5}=+20 \mathrm{~mm}$ seperti terlihat pada gambar 3 . Besar perubahan sudut camber dibatasi sebesar $\pm 1^{\circ}[3]$.

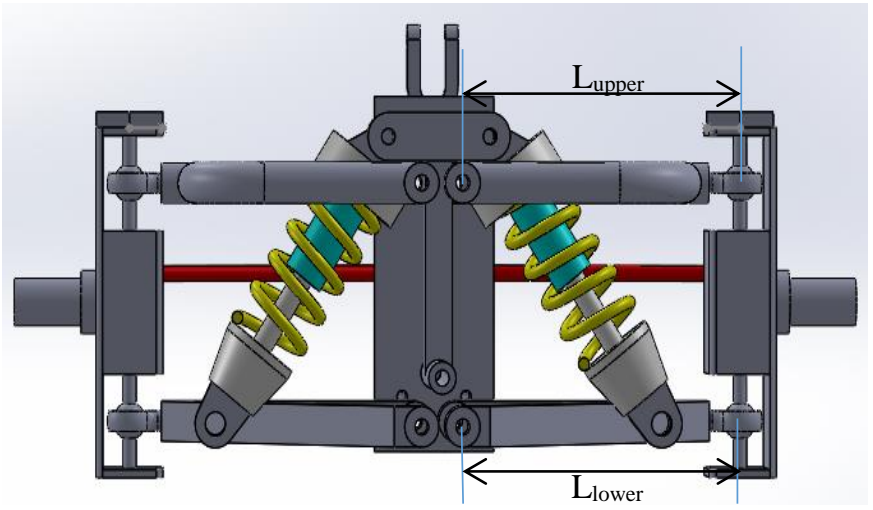

Gambar 3. Panjang upper dan lower control arm.

\section{ANALISA DAN PEMBAHASAN DATA}

\section{A. Data Spesifikasi Kendaraan}

Kendaraan yang dibahas pada tugas akhir kali ini adalah narrow tilting vehicle. Sebuah kendaraan beroda tiga yang memiliki kemampuan memiringkan rangka (tilting) ketika berbelok. Adapun desain kendaraan ini menggunakan konfigurasi tadpole atau dua roda depan dan satu roda belakang [4]. Sistem kemudi menggunakan tie rod dengan ukuran tetap sesuai dengan dimensi kendaraan. Sistem suspensi kendaraan menggunakan jenis quadrilateral [5].

\section{B. Pengaruh Panjang Sambungan Batang Kemudi Terhadap \\ Sudut Belok (Trackwidth 700mm)}

Variabel yang divariasikan dalam simulasi kinematika sistem kemudi narrow tilting vehicle adalah panjang sambungan samping $\left(\mathrm{L}_{\text {side }}\right)$ dan panjang sambungan belakang $\left(\mathrm{L}_{\text {back }}\right)$ batang kemudi. Terdapat 3 variasi nilai $\mathrm{L}_{\text {back }}$ yaitu $50 \mathrm{~mm}, 75 \mathrm{~mm}$, dan $100 \mathrm{~mm}$ dimana pada setiap nilai $\mathrm{L}_{\text {back }}$ terdapat 5 variasi $\mathrm{L}_{\text {side }}$ $90 \mathrm{~mm}, 100 \mathrm{~mm}, 110 \mathrm{~mm}, 120 \mathrm{~mm}$, dan $130 \mathrm{~mm}$. Hasil simulasi kemudian dibandingkan dengan kondisi belok Ackerman.

Gambar 4, 5, dan 6 menunjukkan bahwa perubahan panjang sambungan batang kemudi akan mempengaruhi tren sudut belok yang dihasilkan. Perubahan panjang $\mathrm{L}_{\text {side }}$ batang kemudi akan mempengaruhi rasio antara sudut belok roda dalam $(\delta i)$ dan sudut belok roda luar $(\delta o)$ dimana semakin panjang $\mathrm{L}_{\text {side }}$ maka rasio antara $\delta i / \delta o$ akan semakin besar.

Gambar 7 menunjukkan bahwa perubahan $L_{\text {back }}$ akan mempengaruhi tren sudut belok yang dihasilkan. Dapat dilihat bahwa semakin panjang $\mathrm{L}_{\text {back }}$ maka sudut belok yang dihasilkan semakin menjauhi kondisi Ackerman. Dari ketiga $L_{\text {back }}$ yang disimulasikan, terlihat bahwa geometri dengan $\mathrm{L}_{\text {back }} 50 \mathrm{~mm}$ dan $\mathrm{L}_{\text {side }} 120 \mathrm{~mm}$ paling mendekati kondisi Ackerman untuk trackwidth $700 \mathrm{~mm}$.

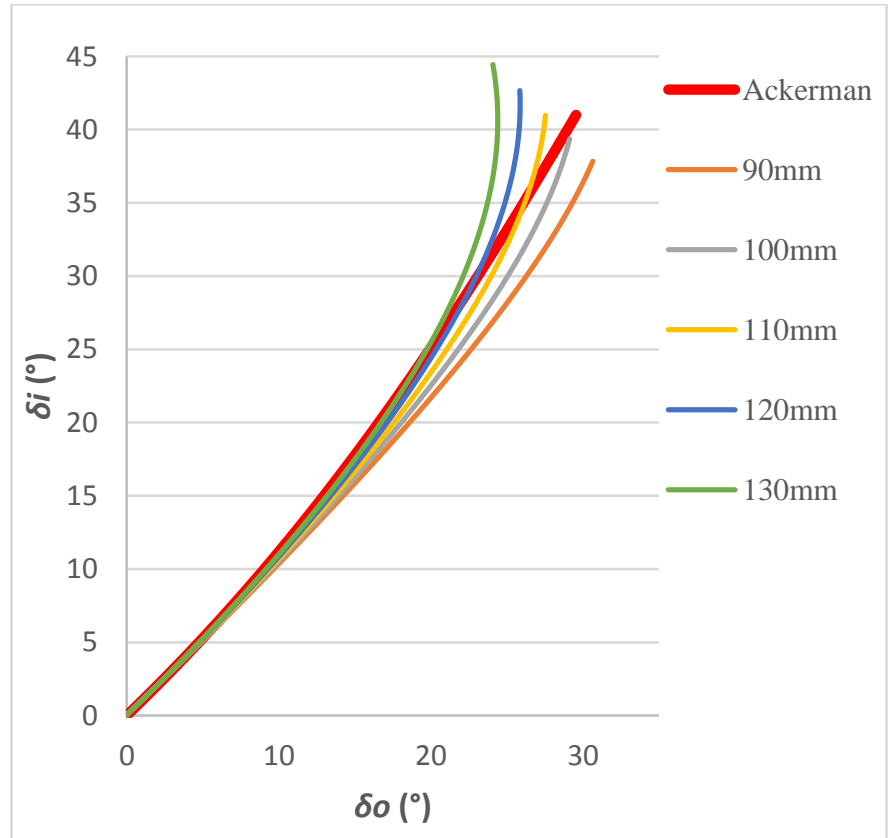

Gambar 4. Hasil sudut belok terhadap kondisi Ackerman dengan $\mathrm{L}_{\text {back }} 50 \mathrm{~mm}$. 


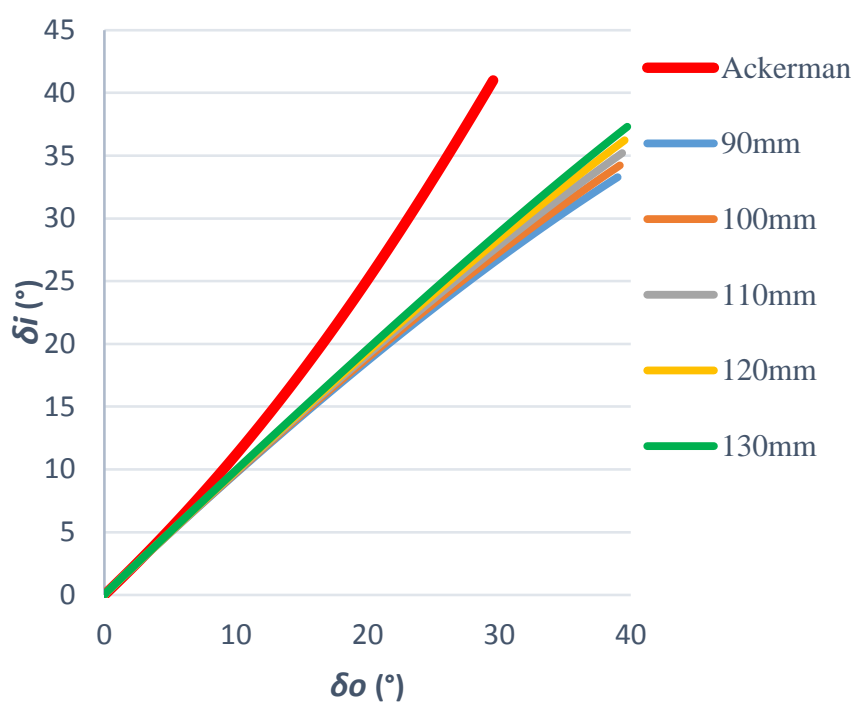

Gambar 5. Hasil sudut belok terhadap kondisi Ackerman dengan $\mathrm{L}_{\text {back }} 75 \mathrm{~mm}$.

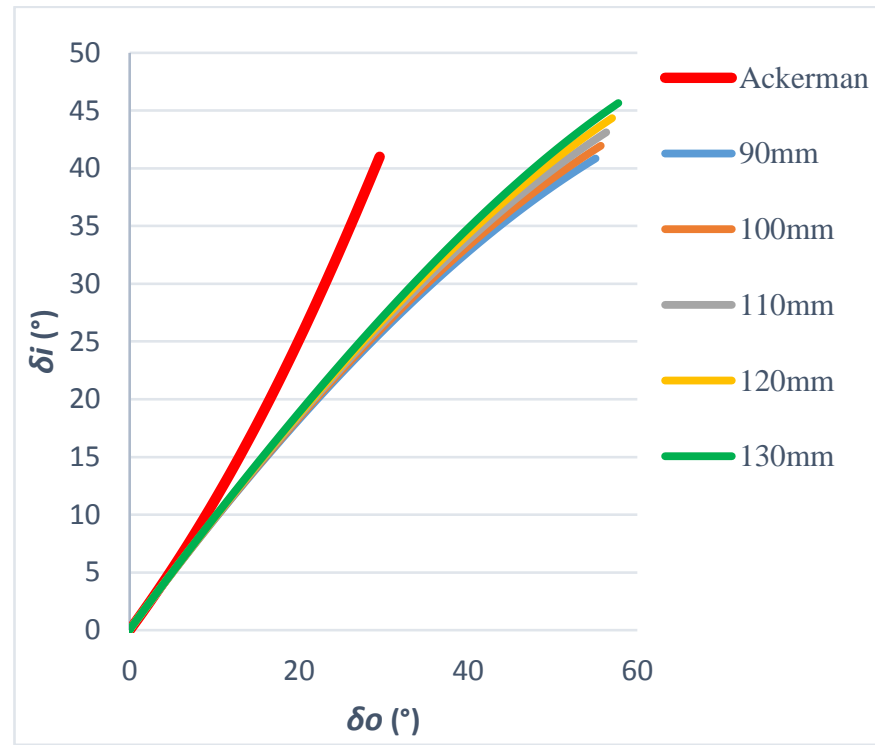

Gambar 6. Hasil sudut belok terhadap kondisi Ackerman dengan $\mathrm{L}_{\text {back }} 100 \mathrm{~mm}$.

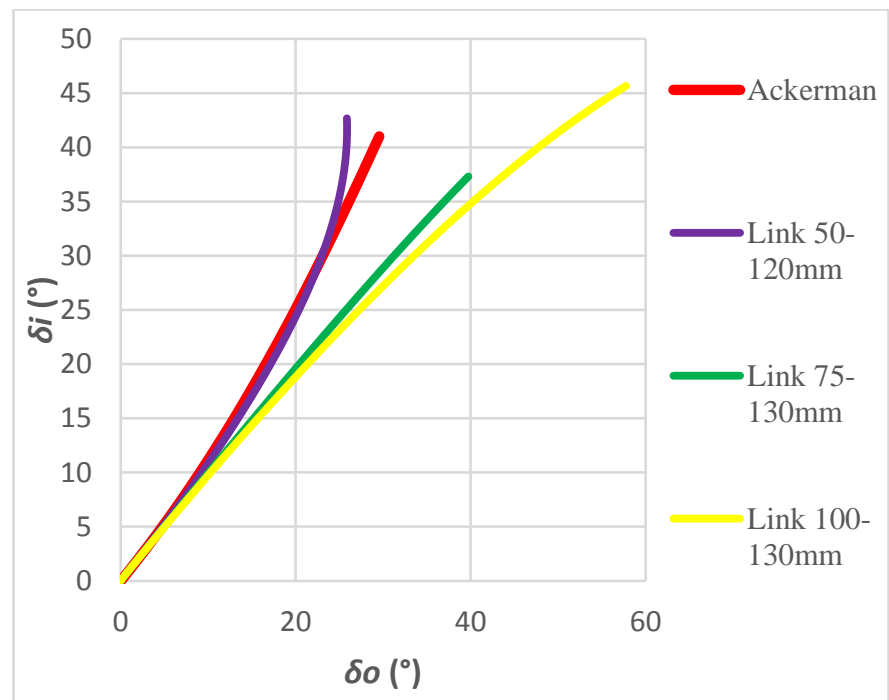

Gambar 7. Hasil sudut belok terhadap kondisi Ackerman tiap nilai $\mathrm{L}_{\text {back }}$ yang paling mendekati kondisi Ackerman.

\section{Pengaruh Panjang Sambungan Batang Kemudi Terhadap} Sudut Belok (Trackwidth 600mm)

Variabel yang divariasikan dalam simulasi kinematika sistem kemudi narrow tilting vehicle adalah panjang sambungan samping $\left(\mathrm{L}_{\text {side }}\right)$ dan panjang sambungan belakang $\left(\mathrm{L}_{\text {back }}\right)$ batang kemudi. Terdapat 3 variasi nilai $\mathrm{L}_{\text {back }}$ yaitu $50 \mathrm{~mm}, 75 \mathrm{~mm}$, dan $100 \mathrm{~mm}$ dimana pada setiap nilai $\mathrm{L}_{\text {back }}$ terdapat 5 variasi $\mathrm{L}_{\text {side }}$ $40 \mathrm{~mm}, 50 \mathrm{~mm}, 60 \mathrm{~mm}, 70 \mathrm{~mm}$, dan $80 \mathrm{~mm}$. Hasil simulasi kemudian dibandingkan dengan kondisi belok Ackerman.

Gambar 8, 9, dan 10 menunjukkan bahwa perubahan panjang $\mathrm{L}_{\text {side }}$ batang kemudi akan mempengaruhi tren sudut belok yang dihasilkan. Perubahan panjang $\mathrm{L}_{\text {side }}$ batang kemudi akan mempengaruhi rasio antara sudut belok roda dalam $(\delta i)$ dan sudut belok roda luar $(\delta o)$ dimana semakin panjang $\mathrm{L}_{\text {side }}$ maka rasio antara $\delta i / \delta o$ akan semakin besar.

Gambar 11 menunjukkan bahwa perubahan $\mathrm{L}_{\text {back }}$ akan mempengaruhi tren sudut belok yang dihasilkan. Dapat dilihat bahwa semakin panjang $\mathrm{L}_{\text {back }}$ maka sudut belok yang dihasilkan semakin menjauhi kondisi Ackerman. Dari ketiga $L_{\text {back }}$ yang disimulasikan, terlihat bahwa geometri dengan $\mathrm{L}_{\text {back }} 50 \mathrm{~mm}$ dan $\mathrm{L}_{\text {side }} 40 \mathrm{~mm}$ paling mendekati kondisi Ackerman untuk trackwidth $600 \mathrm{~mm}$.

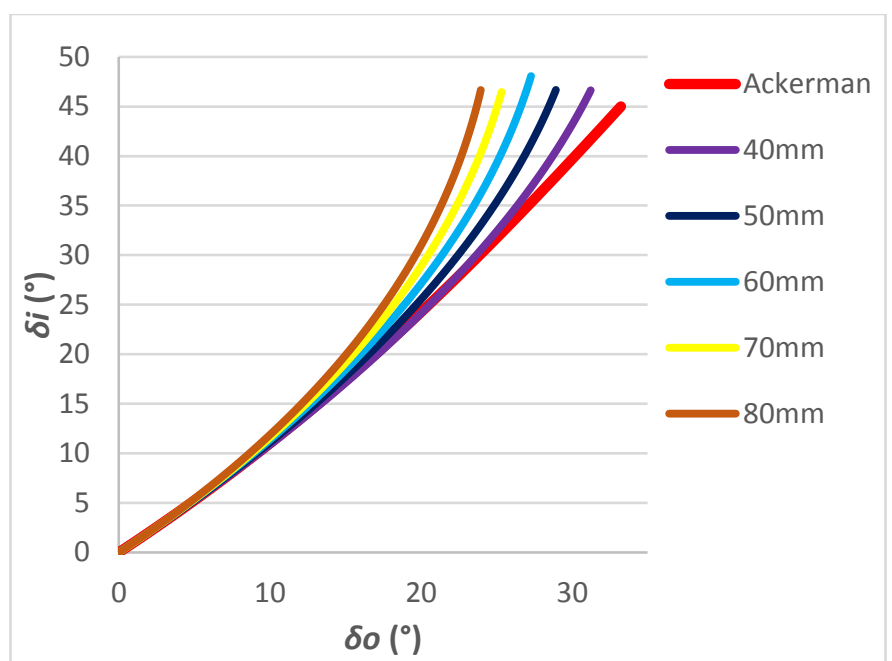

Gambar 8. Hasil sudut belok terhadap kondisi Ackerman dengan $\mathrm{L}_{\text {back }} 50 \mathrm{~mm}$.

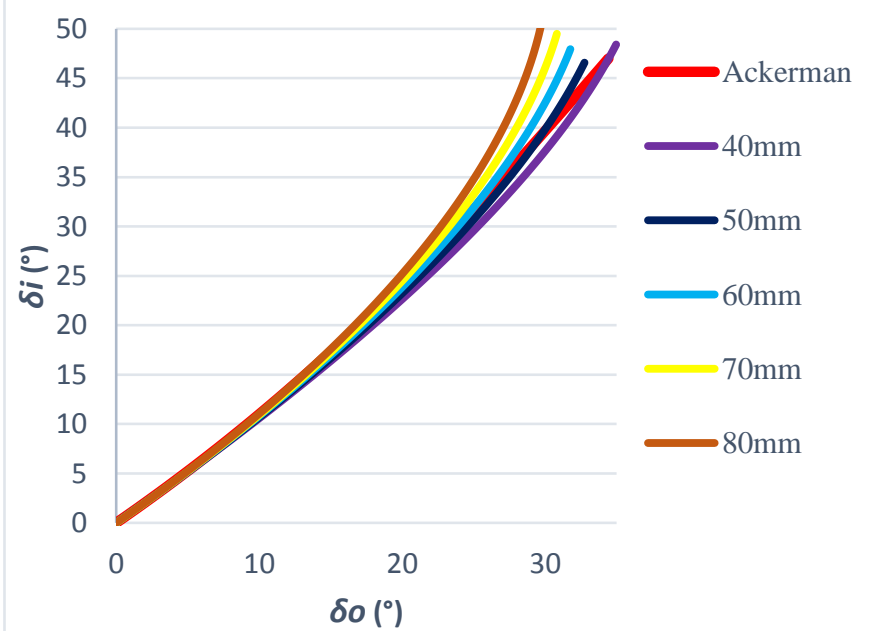

Gambar 9. Hasil sudut belok terhadap kondisi Ackerman dengan $\mathrm{L}_{\text {back }} 75 \mathrm{~mm}$. 


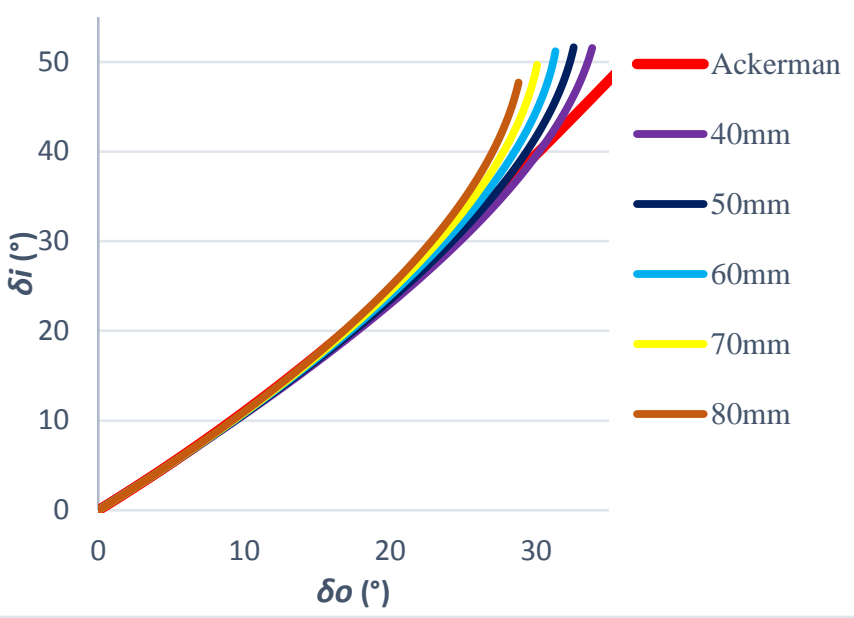

(c)

Gambar 10. Hasil sudut belok terhadap kondisi Ackerman dengan $\mathrm{L}_{\text {back }} 100 \mathrm{~mm}$.

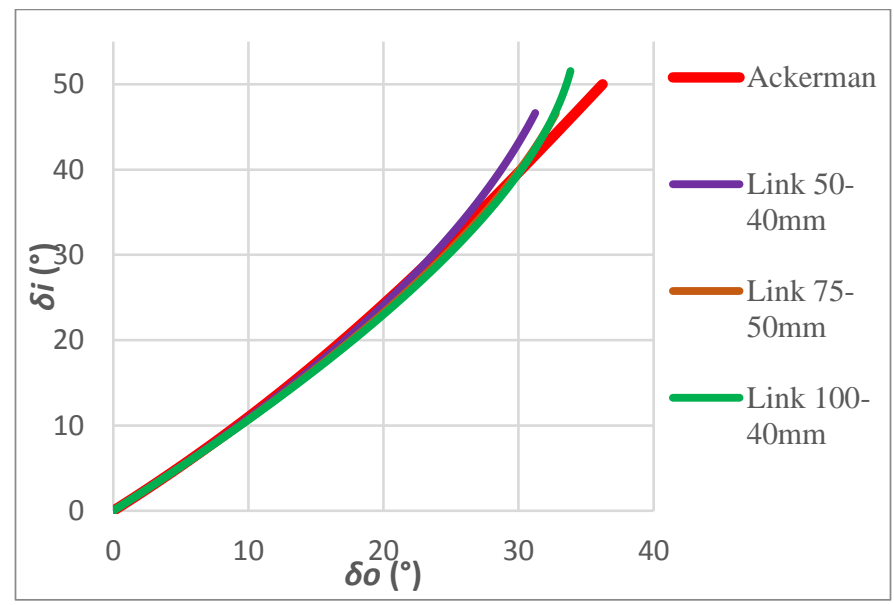

Gambar 11. Hasil sudut belok terhadap kondisi Ackerman tiap nilai $\mathrm{L}_{\text {back }}$ yang paling mendekati kondisi Ackerman

\section{Pengaruh Panjang Sambungan Batang Kemudi \\ Terhadap Sudut Belok (Trackwidth 500mm)}

Simulasi kinematika dengan variasi panjang $\mathrm{L}_{\text {side }}$ juga dilakukan pada model dengan trackwidth sebesar $500 \mathrm{~mm}$. Terdapat 5 variasi panjang $\mathrm{L}_{\text {side }}$ yaitu $40 \mathrm{~mm}, 50 \mathrm{~mm}, 60 \mathrm{~mm}$, $70 \mathrm{~mm}$, dan $80 \mathrm{~mm}$. Hasil simulasi kinematika kemudian dibandingkan dengan kondisi belok Ackerman.

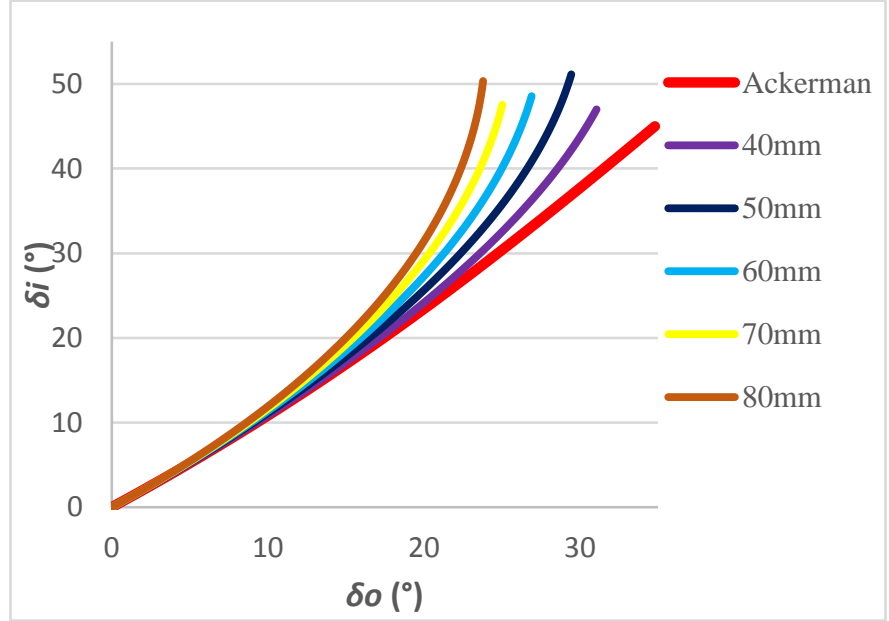

Gambar 12. Hasil sudut belok terhadap kondisi Ackerman dengan $\mathrm{L}_{\text {back }} 50 \mathrm{~mm}$.

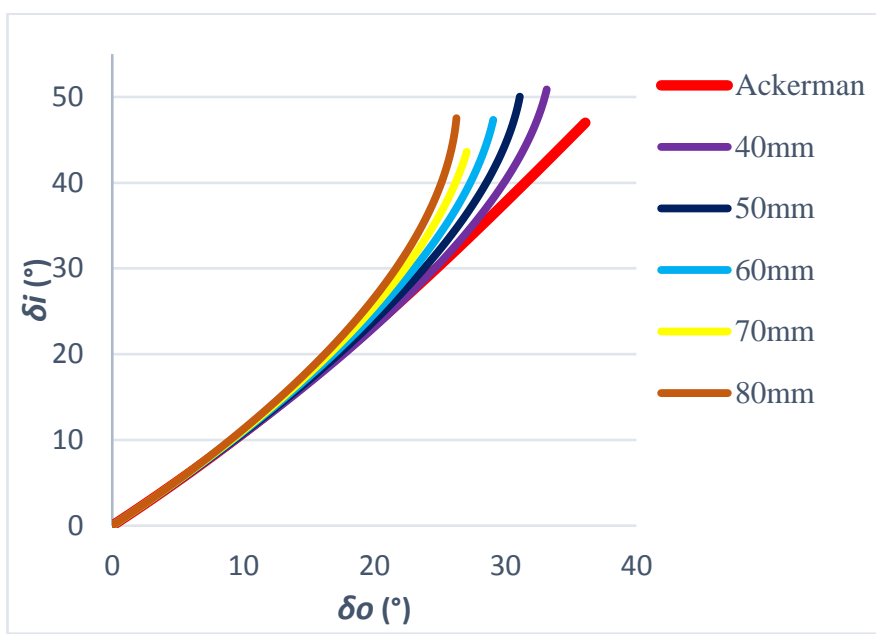

(b)

Gambar 13. Hasil sudut belok terhadap kondisi Ackerman dengan $\mathrm{L}_{\text {back }} 75 \mathrm{~mm}$.

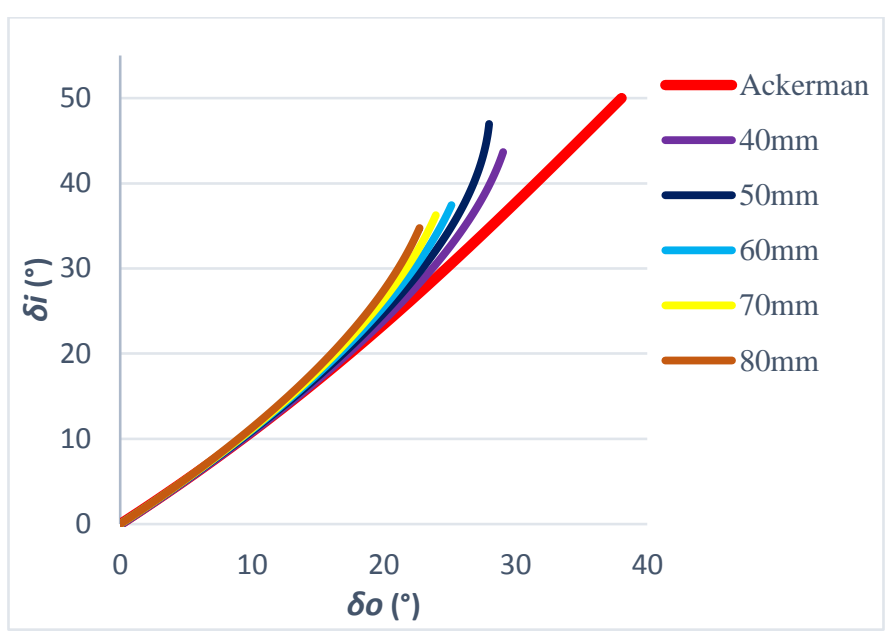

(c)

Gambar 14. Hasil sudut belok terhadap kondisi Ackerman dengan $\mathrm{L}_{\text {back }} 100 \mathrm{~mm}$.

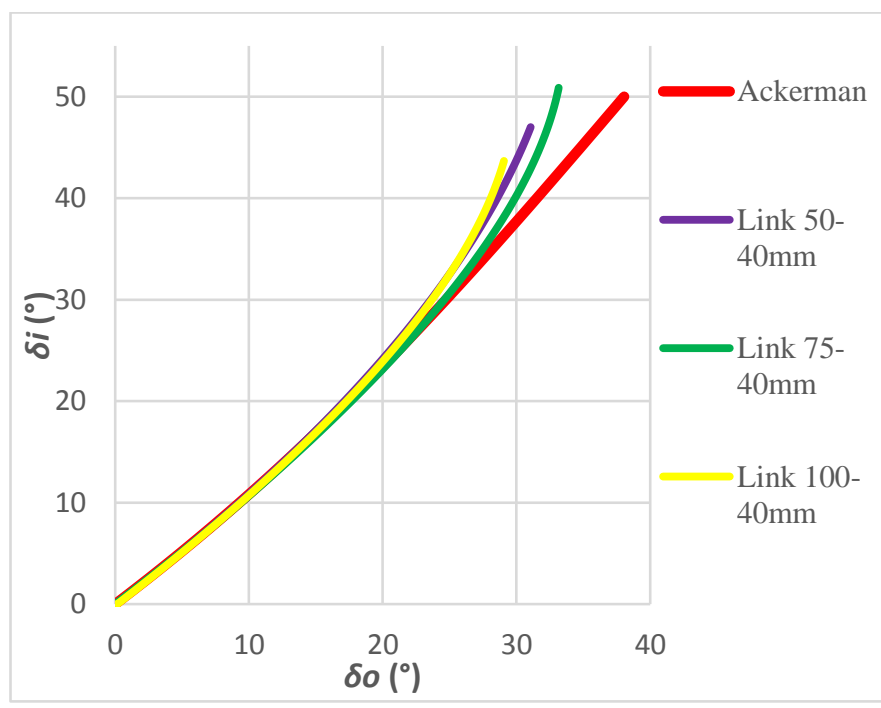

Gambar 15. Hasil sudut belok terhadap kondisi Ackerman tiap nilai $\mathrm{L}_{\text {back }}$ yang paling mendekati kondisi Ackerman.

Dari gambar 12, 13, dan 14 diketahui bahwa perubahan panjang $\mathrm{L}_{\text {side }}$ akan mempengaruhi tren sudut belok yang dihasilkan. Perubahan panjang $\mathrm{L}_{\text {side }}$ akan mempengaruhi rasio 
antara sudut belok roda dalam $(\delta i)$ dan sudut belok roda luar ( $\delta o$ ) dimana semakin panjang sambungan maka rasio antara $\delta i / \delta o$ akan semakin besar.

Dari gambar 15 terlihat bahwa perubahan nilai $\mathrm{L}_{\text {back }}$ akan mempengaruhi tren sudut belok yang dihasilkan. Dapat dilihat bahwa nilai $L_{\text {back }}$ sebesar $75 \mathrm{~mm}$ paling mendekati kondisi Ackerman diikuti oleh lebar $100 \mathrm{~mm}$ dan 50mm. Dari ketiga $\mathrm{L}_{\text {back }}$ yang disimulasikan, terlihat bahwa geometri dengan $\mathrm{L}_{\text {back }}$ $75 \mathrm{~mm}$ dan $\mathrm{L}_{\text {side }} 40 \mathrm{~mm}$ paling mendekati kondisi Ackerman untuk trackwidth $500 \mathrm{~mm}$.

\section{E. Pengaruh Panjang Upper Control Arm Terhadap}

Perubahan Sudut Camber (Trackwidth 700mm)

Pada sistem suspensi depan kendaraan dilakukan simulasi kinematika dengan pemberian beban vertikal sehingga knuckle bergerak ke atas (bound) dan ke bawah (rebound) dengan jarak tertentu. Parameter yang diukur adalah perubahan sudut camber. Sistem kemudi dikunci pada saat simulasi sehingga roda selalu mengarah ke depan.

Gambar 16 menunjukkan bahwa perubahan panjang upper control arm berpengaruh pada range perubahan sudut camber yang dihasilkan dimana semakin besar perbedaan panjang upper control arm dengan lower control arm maka range perubahan sudut camber semakin besar. Hasil simulasi sesuai dengan teori, yaitu jika perbedaan panjang antara upper control arm dan lower control arm semakin besar maka range perubahan sudut camber juga semakin besar.

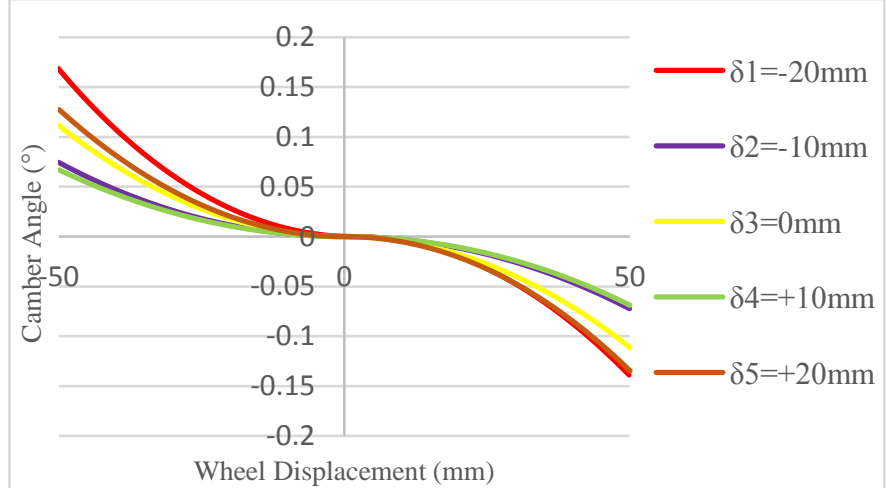

Gambar 16. Grafik perubahan sudut camber terhadap wheel displacement pada trackwidth $700 \mathrm{~mm}$.

Untuk mencegah camber positif pada roda, sistem suspensi dirancang sedemikian rupa sehingga ketika roda terangkat ke atas (bounce) maka sudut camber harus bergerak ke arah negatif. Dari gambar 4.15 terlihat bahwa semua variasi panjang upper control arm memenuhi kriteria tersebut. Dari semua variasi yang memenuhi kriteria, perubahan sudut camber masih berada dalam range yang wajar yaitu maksimal sebesar $\pm 0,2^{\circ}$.

\section{F. Pengaruh Panjang Upper Control Arm Terhadap Perubahan Sudut Camber (Trackwidth 600mm)}

Pada sistem suspensi depan kendaraan dilakukan simulasi kinematika dengan pemberian beban vertikal sehingga knuckle bergerak ke atas (bound) dan ke bawah (rebound) dengan jarak tertentu. Parameter yang diukur adalah perubahan sudut camber. Sistem kemudi dikunci pada saat simulasi sehingga roda selalu mengarah ke depan. Terdapat 5 variasi panjang upper control arm terhadap lower control arm yaitu -20mm, $10 \mathrm{~mm}, 0 \mathrm{~mm},+10 \mathrm{~mm}$, dan $+20 \mathrm{~mm}$.

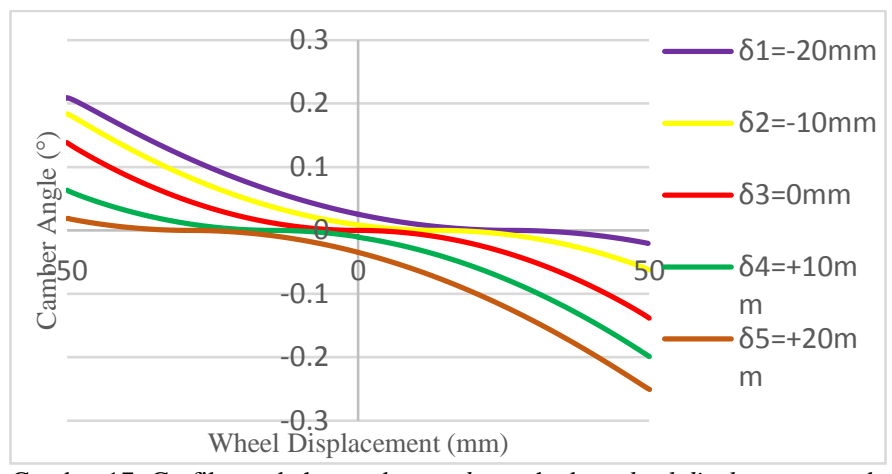

Gambar 17. Grafik perubahan sudut camber terhadap wheel displacement pada trackwidth $600 \mathrm{~mm}$.

Gambar 17 menunjukkan bahwa perubahan panjang upper control arm berpengaruh pada perubahan sudut camber terhadap wheel displacement. Pengurangan panjang upper control arm menyebabkan camber banyak berada di daerah positif sedangkan penambahan panjang upper control arm menyebabkan camber banyak berada di daerah negatif. Hal ini disebabkan oleh perbedaan panjang antara upper dan lower control arm yang mengakibatkan perbedaan laju perubahan sudut camber pada masing-masing control arm.

Untuk mencegah camber positif pada roda, sistem suspensi dirancang sedemikian rupa sehingga ketika roda terangkat ke atas (bounce) maka sudut camber harus bergerak ke arah negatif. Terlihat dari gambar 13 bahwa semua variasi panjang upper control arm memenuhi kriteria tersebut. Dari semua variasi yang memenuhi kriteria, perubahan sudut camber masih berada dalam range yang wajar yaitu maksimal sebesar $\pm 0,2^{\circ}$.

\section{G. Pengaruh Panjang Upper Control Arm Terhadap Perubahan Sudut Camber (Trackwidth 500mm)}

Pada sistem suspensi depan kendaraan dilakukan simulasi kinematika dengan pemberian beban vertikal sehingga knuckle bergerak ke atas (bound) dan ke bawah (rebound) dengan jarak tertentu. Parameter yang diukur adalah perubahan sudut camber. Sistem kemudi dikunci pada saat simulasi sehingga roda selalu mengarah ke depan.

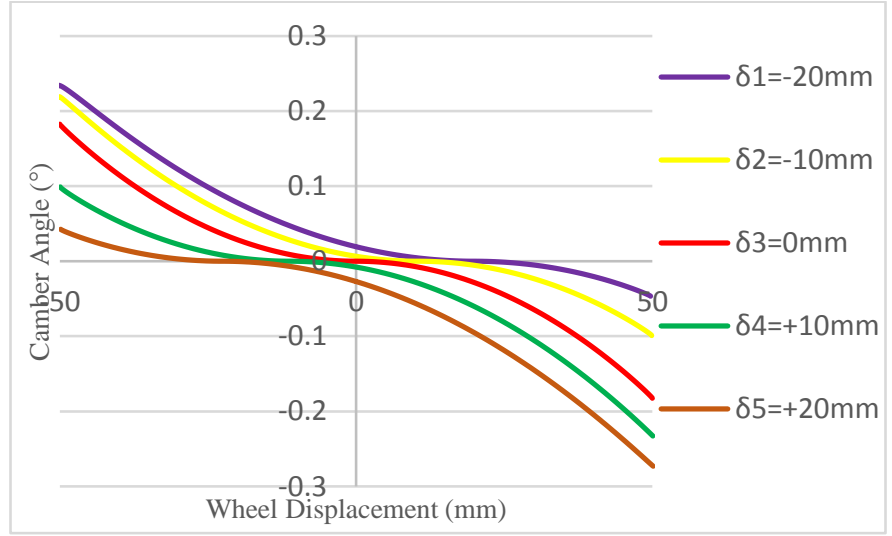

Gambar 18. Grafik perubahan sudut camber terhadap wheel displacement pada trackwidth $500 \mathrm{~mm}$ 
Gambar 18 menunjukkan bahwa perubahan panjang upper control arm berpengaruh pada perubahan sudut camber terhadap wheel displacement. Pengurangan panjang upper control arm menyebabkan camber banyak berada di daerah positif sedangkan penambahan panjang upper control arm menyebabkan camber banyak berada di daerah negatif. Hal ini disebabkan oleh perbedaan panjang antara upper dan lower control arm yang mengakibatkan perbedaan laju perubahan sudut camber pada masing-masing control arm.

Untuk mencegah camber positif pada roda, sistem suspensi dirancang sedemikian rupa sehingga ketika roda terangkat ke atas (bounce) maka sudut camber harus bergerak ke arah negatif. Terlihat dari gambar 14 bahwa semua variasi panjang upper control arm memenuhi kriteria tersebut. Dari semua variasi yang memenuhi kriteria, perubahan sudut camber masih berada dalam range yang wajar yaitu maksimal sebesar $\pm 0,2^{\circ}$.

\section{KESIMPULAN}

Dari perancangan dan simulasi kinematika sistem kemudi dan sistem suspensi narrow tilting vehicle yang telah dilakukan, rancangan sistem kemudi narrow tilting vehicle yang paling mendekati kondisi Ackerman diperoleh pada trackwidth sebesar $600 \mathrm{~mm}$ dan panjang sambungan belakang $\mathrm{L}_{\text {back }} 50 \mathrm{~mm}$ dan sambungan samping $\mathrm{L}_{\text {side }} 40 \mathrm{~mm}$. Untuk geometri sistem kemudi yang paling mendekati kondisi Ackerman, variasi panjang upper control arm yang sama dengan lower control arm telah dipilih.

\section{DAFTAR PUSTAKA}

[1] Jazar, Reza N. 2008. "Vehicle Dynamics: Theory and Applications". New York: Springer.

[2] Milliken, William F. and Milliken, Douglas L., 1995. "Race Car Vehicle Dynamics". Warrendale: Society of Automotive Engineers.

[3] Yang, S., Bao, Y., Liu, Y. and Li, C., 2014. "Kinematic analysis of the double wishbone suspension in ADAMS". In Transportation Electrification Asia-Pacific (ITEC Asia-Pacific), 2014 IEEE Conference and Expo (pp. 1-5): IEEE.

[4] Hillen, Brittany. "Toyota i-Road Urban Tandem Two-Seater Vehicle Specs Detailed at CEATEC 2013", http://www.slashgear.com. (diakses 20 Maret 2016).

[5] Knowles, Don. 2002. "Automotive Suspension and Steering Systems". Cengage Learning. 